\title{
XI. ročník konference JuFoS 2019
}

\section{$11^{\text {th }}$ conference JuFoS 2019}

\author{
Tereza Jandásková, Tomáš Hrdlička*
}

Vysoké učeni technické v Brně, Ústav soudního inženýrstvi

\begin{abstract}
The article deals with $11^{\text {th }} \mathrm{JuFoS} 2019$ conference. The conference was held at the Institute of Forensic Engineering at BUT on April 11, 2019. This year's conference was attended by 34 participants from the Czech and Slovak Republics.
\end{abstract}

Keywords: conference, Ph.D. study, forensic, science, accident analysis, risk, engineering.

Situace na realitním trhu pak pro sekci Stavebnictví a oceňování nemovitostí přednesl Bc. Radim Kučera.

V obou sekcích nejdříve proběhly zmíněné tematické přednášky a poté následovalo jednání studentů. Mezi jednotlivými přednáškami bylo možné diskutovat, řešit aktuální problematiku a navazovat nové kontakty při kávě.

Ke každému ročníku doktorské konference neodmyslitelně patří také ocenění nejvíce přínosných příspěvků, které na konferenci zazněly.

Za sekci Analýza silničních nehod byly oceněny příspěvky Ing. Pavlíny Moravcové, Ing. Kateřiny Bucsuházy a Ing. et Ing. Martina Bilíka, Ph.D., který se zabýval určením deformační energie pro použití v oblasti soudního inženýrství. Dalším oceněným byl př́íspěvek Ing. Romana Mikulce, ve kterém byly simulačně modelovány jízdní zkoušky ustáleného zatáčení (tzv. kruhové zkoušky) provedené s vozidlem Škoda Superb III. V neposlední řadě byl oceněn také př́spěvek Ing. Romana Šůstka. Ten se věnoval zobecnění přístupu stanovení významných parametrů tvářecího stroje s možností jejich dalšího využití.

Také v sekci Stavebnictví a oceňování nemovitostí byly oceněny tř̌i nejvíce přínosné příspěvky. Oceněn byl příspěvek Ing. Tomáše Hrdličky a Ing. Terezy Opálkové na téma Vliv certifikace budov na jejich cenu, který řešil dopady environmentálních certifikací na výši nájemného a prodejní cenu rezidenčních a kancelářských budov. Dalším oceněným byl př́íspěvek Ing. Karly Hávy, pojednávající o řešení problému určování významných faktorů ovlivňujících obvyklé náklady na stavební dodávky materiálů 
a prací. V neposlední řadě byl oceněn také příspěvek Ing. Jána Hollého a Ing. Martiny Jurigové, který se zabýval vyhodnocením vybraných vad u rekonstruovaného hliněného domu.

Konference se konala v komorním duchu 34 účastníků z České a Slovenské republiky. Za podpory Asociace znalců a odhadců České republiky, pojištovny Generali a Centra dopravního výzkumu, v.v.i.: Výzkum v dopravě. Záštitu nad konferencí převzal rektor VUT prof. RNDr. Ing. Petr Štěpánek, CSc. a primátorka města Brna JUDr. Markéta Vaňková.

Vybrané př́spěvky publikované $\mathrm{v}$ rámci konference budou vydány také v časopise Soudní inženýrství. Sborník příspěvků v plném znění je dostupný na webových stránkách www.jufos.cz.
Letošní ročník konference byl unikátní také postojem organizátorů vůči životnímu prostředí. Při přípravách konference i v jejím průběhu byla vynaložena snaha o redukci produkce odpadu. Plastové láhve tak nahradily kompostovatelné kelímky a voda z kohoutku, sborník na CD byl pak nahrazen QR kódem. Věríme, že i v dalších ročních konference bude brán ohled na životní prostředí.

Za organizační tým přejeme konferenci další úspěšné ročníky a zajímavé příspěvky.

\section{Správná citace:}

Jandásková, T., Hrdlička, T. XI. ročník konference JuFoS 2019. Soudní inženýrství, 2019, 30(2), 64-65. DOI: http://dx.doi.org./10.13164/ SI.2019.2.64. ISSN 1211-443X. 